\title{
The changing demographics of women living with HIV/AIDS in southern Alberta from 1982 to 2006
}

\author{
Liana Hwang BSc MD CCFP ${ }^{1}$, Jesse Raffa BSc, MSc ${ }^{2}$, Michael John Gill MB FRCPC ${ }^{3}$
}

\begin{abstract}
L Hwang, J Raffa, MJ Gill. The changing demographics of women living with HIV/AIDS in southern Alberta from 1982 to 2006. Can J Infect Dis Med Microbiol 2012;23(2):e36e40.
\end{abstract}

INTRODUCTION: Women account for a growing proportion of HIV infections in Canada. This has implications with respect to prevention, diagnosis and treatment.

OBJECTIVE: To describe the female population presenting for HIV care in southern Alberta and to examine the impact of opt-out pregnancy screening.

METHODS: A retrospective review of demographic and clinical characteristics of all patients presenting to the Southern Alberta HIV Clinic (SAC) care program from 1982 to 2006, was performed.

RESULTS: The proportion of newly diagnosed patients who were female increased from $7.5 \%$ before 1998 to $21.5 \%$ after 1998 . Women were more likely to be from vulnerable populations, such as intravenous drug users $(31.3 \%$ versus $13.7 \%, \mathrm{P}<0.001)$, aboriginals/Métis $(21.5 \%$ versus $8.7 \%, \mathrm{P}<0.001)$, blacks $(28.9 \%$ versus $4.9 \%, \mathrm{P}<0.001)$ and immigrants $(36.6 \%$ versus $14.7 \%, \mathrm{P}<0.001)$. Heterosexual intercourse was the main risk factor for HIV acquisition (43.7\%). Women were less likely than men to have requested HIV testing (20.9\% versus $37.8 \%, \mathrm{P}<0.001)$. Opt-out pregnancy screening accounted for $12.7 \%$ of HIV-positive tests in women, following its introduction in 1998. Of the women diagnosed by pregnancy screening, $62.1 \%$ were from HIVendemic countries. There was an association between reason for testing and CD4 count at presentation; women who requested their HIV test had higher median CD4 counts than those diagnosed because of illness (478 cells/mL, interquartile range $[\mathrm{IQR}]=370$ cells $/ \mathrm{mL}$ versus 174 cells/mL, $\mathrm{IQR}=328$ cells $/ \mathrm{mL}, \mathrm{P}<0.001$ ) or pregnancy screening $(478$ cells $/ \mathrm{mL}$, $\mathrm{IQR}=370$ cells $/ \mathrm{mL}$ versus 271 cells $/ \mathrm{mL}, \mathrm{IQR}=256$ cells $/ \mathrm{mL}, \mathrm{P}=0.001$ ). CONCLUSIONS: Women were less likely than men to have requested HIV testing and were more likely to be diagnosed by population-based screening methods. Women, especially vulnerable groups, account for a growing number and proportion of newly diagnosed HIV infections in Alberta. The implications of expanded screening in this population merit further consideration.

Key Words: HIVIAIDS, Pregnancy screening, Testing behaviours, Women

A the end of 2008, 65,000 people in Canada were living with HIV/ AIDS (1). Despite increasing awareness of HIV/AIDS, it is estimated that $26 \%$ of HIV-positive Canadians do not know their status (1). This undiagnosed population presents a challenge in terms of preventing transmission (2). Additionally, these patients are unable to benefit from early initiation of highly active antiretroviral therapy (HAART), which could improve health and survival (3) and help to avoid some of the financial costs associated with late presentation (4).

Similar to the rest of the world (5), Canada is experiencing a feminization of the HIV epidemic, with women accounting for $28 \%$
L'évolution de la démographie des femmes qui vivaient avec le VIH-sida dans le sud de l'Alberta entre 1982 et 2006

HISTORIQUE : Les femmes représentent une proportion croissante d'infections par le VIH au Canada. Ce constat a des conséquences sur la prévention, le diagnostic et le traitement.

OBJECTIFS : Décrire la population de femmes consultant pour recevoir dessoins du VIH dans le sud de l'Alberta et examiner les conséquences du test de dépistage systématique pendant la grossesse.

MÉTHODOLOGIE : Les chercheurs ont procédé à une analyse rétrospective des caractéristiques démographiques et cliniques de toutes les patientes qui avaient consulté au programme de soins de la clinique du VIH du sud de l'Alberta (CSA) entre 1982 et 2006.

RÉSULTATS : La proportion de patientes nouvellement diagnostiquées est passée de 7,5 \% avant 1998 à 21,5\% après 1998. Les femmes étaient plus susceptibles de provenir de populations vulnérables, telles que les consommatrices de drogues intraveineuses (31,3\% par rapport à $13,7 \%, \mathrm{P}<0,001)$, les Autochtones et les Métis (21,5\% par rapport à $8,7 \%, \mathrm{P}<0,001)$, les Noires $(28,9 \%$ par rapport à $4,9 \%, \mathrm{P}<0,001)$ et les immigrantes $(36,6 \%$ par rapport à $14,7 \%, \mathrm{P}<0,001)$. Les relations hétérosexuelles étaient le principal facteur de risque d'acquisition du VIH $(43,7 \%)$. Les femmes étaient moins susceptibles d'avoir demandé un test du VIH que les hommes (20,9\% par rapport à 37,8 \%, P<0,001). Après la mise en œuvre du test de dépistage systématique pendant la grossesse en 1998, ce test représentait 12,7 \% des tests positifs au VIH chez les femmes. Chez les femmes diagnostiquées au moyen de ce test, $62,1 \%$ provenaient de pays endémiques au VIH. On constatait une association entre la raison de subir le test et la numération de $\mathrm{CD}_{4}$ à la présentation. Les femmes qui demandaient de subir le test du VIH présentaient une numération de $\mathrm{CD}_{4}$ médiane plus élevée que celles qui étaient diagnostiquées à cause d'une maladie (478 cellules $/ \mathrm{mL}$, écart interquartile [ÉIQ] $=370$ cellules $/ \mathrm{mL}$ par rapport à 174 cellules $/ \mathrm{mL}$, ÉIQ $=328$ cellules $/ \mathrm{mL}, \mathrm{P}<0,001$ ) ou d'un test pendant la grossesse $(478$ cellules $/ \mathrm{mL}, E ́ \mathrm{IQ}=370$ cellules $/ \mathrm{mL}$ par rapport à 271 cellules $/ \mathrm{mL}$, ÉIQ=256 cellules $/ \mathrm{mL}, \mathrm{P}=0,001)$.

CONCLUSIONS : Les femmes étaient moins susceptibles que les hommes d'avoir demandé un test de dépistage du VIH, mais plus susceptibles d'avoir été diagnostiquées par des méthodes de dépistage en population. Les femmes, en particulier les groupes vulnérables, représentent une proportion et un nombre croissant des nouvelles infections par le VIH en Alberta. Les conséquences d'un dépistage élargi au sein de cette population méritent un examen plus approfondi.

\footnotetext{
${ }^{1}$ Department of Family Medicine, Calgary Health Region, Calgary, Alberta; ${ }^{2}$ Department of Statistics and Actuarial Science, University of

Waterloo, Waterloo, Ontario; ${ }^{3}$ Southern Alberta HIV Clinic, Sheldon M Chumir Health Centre, Calgary, Alberta

Correspondence: Liana Hwang, PO Box 65128, North Hill RPO, Calgary, Alberta T2N 4T6. Telephone 403-862-0136,

fax 403-724-0006, e-mail liana_hwang@hotmail.com
} 


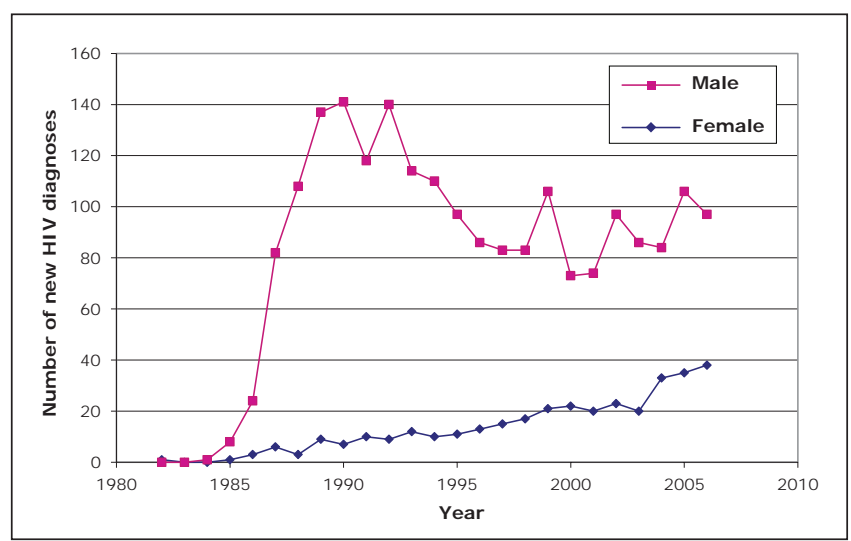

Figure 1) Absolute number of new HIV diagnoses in southern Alberta from 1982 to 2006

and Asian women more likely to test late (8). Poverty, marginalization, social isolation and sexual violence increase women's vulnerability to HIV infection $(5,8)$ and likely also influence testing behaviours.

The introduction of opt-out pregnancy screening in Alberta in 1998 led to a dramatic increase in HIV testing among women. More than $95 \%$ of women accessing prenatal care in Alberta are screened for HIV, leading to a positive test rate of 3.3 in 10,000 in 2000 (9). The sociodemographic and clinical characteristics of women diagnosed as a result of pregnancy screening in northern Alberta have been described recently (10).

Although few Canadian studies have focused on women, factors associated with HIV testing have been described previously, with only $35 \%$ of Canadians having ever been tested for HIV and less than $17 \%$ reporting voluntary testing. Among those who had been tested, the highest rates were seen among those reporting at least one risk factor for HIV. Even so, $40 \%$ of injection drug users (IDUs), and $70 \%$ of men and $62 \%$ of women reporting high-risk sex partners had never been tested (11). Similarly, laboratory surveillance data in Alberta suggests that HIV testing is accessed infrequently, with $70 \%$ of newly diagnosed individuals discovering their status at their first HIV test. Even repeat testers, many of whom had risk factors for HIV, had a median interval of almost two years between their last negative and first positive test (12).

A longitudinal database has been maintained on all patients receiving HIV care in southern Alberta since 1982, presenting a unique opportunity to describe epidemiological trends, reasons for testing and the impact of pregnancy screening on the female population seeking HIV/AIDS treatment over the entire history of HIV within a complete geographical region. We wished to define the changing clinical and sociodemographic characteristics of the female population presenting for HIV care in southern Alberta over time with particular focus on reasons for HIV testing and the impact of opt-out pregnancy screening. We also examined the clinical and sociodemographic differences between women and men with HIV in southern Alberta.

\section{METHODS}

Study participants and design

All HIV-positive individuals referred for HIV assessment and care are automatically enrolled in the Southern Alberta Cohort. The cohort includes all patients in southern Alberta who receive or have received HIV care through the regional HIV care program in Calgary. Access to provincially funded HIV care, including HIV specific laboratory tests and free antiretroviral therapy, is provided exclusively through this program. Routine administrative, demographic, clinical, inpatient and outpatient data are collected at all visits and are maintained within the Southern Alberta Cohort database. The present study included all HIV-infected patients initiating care within the regional centralized HIV care program from January 1982 to December 2006. Ethics approval was obtained for analysis of non-nominal data.
TABLE 1

Characteristics of female patients accessing HIV care in southern Alberta over time

\begin{tabular}{|c|c|c|c|}
\hline & $1982-1996(n=95)$ & $1997-2006(n=244)$ & $\mathbf{P}$ \\
\hline $\begin{array}{l}\text { Age at presentation, } \\
\text { years, mean } \pm S D\end{array}$ & $33.4 \pm 12.9$ & $32.7 \pm 9.7$ & 0.63 \\
\hline Median education level & High school & High school & \\
\hline Birth outside of Canada & $19(20.0)$ & $105(43.0)$ & $<0.001$ \\
\hline \multicolumn{4}{|l|}{ Ethnicity } \\
\hline Caucasian & $62(65.3)$ & $80(32.8)$ & $<0.001$ \\
\hline Black & $12(12.6)$ & $86(35.2)$ & $<0.001$ \\
\hline Aboriginal/Métis & $13(13.7)$ & $60(24.5)$ & 0.031 \\
\hline Other & $5(5.3)$ & $11(4.5)$ & 0.76 \\
\hline Unknown & $3(3.2)$ & $7(2.9)$ & \\
\hline \multicolumn{4}{|l|}{ Marital status } \\
\hline Single & $4(4.2)$ & $64(26.2)$ & $<0.001$ \\
\hline Married/common law & $43(15.8)$ & $80(9.4)$ & 0.17 \\
\hline $\begin{array}{l}\text { Divorced/separated/ } \\
\text { widower }\end{array}$ & $23(24.2)$ & $46(18.9)$ & 0.57 \\
\hline Never married & $23(24.2)$ & $21(8.6)$ & 0.001 \\
\hline Unknown & $2(2.1)$ & $33(13.5)$ & \\
\hline \multicolumn{4}{|l|}{ Risk factor for HIV } \\
\hline Heterosexual & $56(58.9)$ & $92(37.7)$ & $<0.001$ \\
\hline $\begin{array}{l}\text { Heterosexual and } \\
\text { endemic area }\end{array}$ & $3(3.2)$ & $62(25.4)$ & $<0.001$ \\
\hline Intravenous drug use & $26(27.4)$ & $82(33.6)$ & 0.26 \\
\hline Homosexual & $0(0.0)$ & $1(0.4)$ & $<0.001$ \\
\hline Blood transfusion & $11(11.6)$ & $5(2.0)$ & 0.001 \\
\hline Maternal fetal & $1(1.1)$ & $1(0.4)$ & 0.51 \\
\hline Unknown & $0(0.0)$ & $1(0.4)$ & \\
\hline \multicolumn{4}{|l|}{ Reason for testing } \\
\hline Patient request & $16(16.8)$ & $55(22.5)$ & 0.20 \\
\hline Physician request & $19(20.0)$ & 46 (18.9) & 0.90 \\
\hline Contact & $25(26.3)$ & $25(10.2)$ & $<0.001$ \\
\hline Illness & $22(23.2)$ & $39(16.0)$ & 0.16 \\
\hline $\begin{array}{l}\text { Routine pregnancy } \\
\text { screening* }\end{array}$ & $0(0.0)$ & $29(11.9)$ & $<0.001$ \\
\hline Immigration & $1(1.1)$ & $30(12.3)$ & 0.011 \\
\hline Insurance & $4(4.2)$ & $5(2.0)$ & 0.30 \\
\hline Blood & $8(8.4)$ & $1(0.4)$ & 0.0040 \\
\hline Other screening & $0(0.0)$ & $7(2.9)$ & $<0.001$ \\
\hline Unknown & $0(0.0)$ & $7(2.9)$ & \\
\hline $\begin{array}{l}\text { CD4 count at presentation, } \\
\text { median (IQR) }\end{array}$ & $342(450)$ & 347 (345) & 0.93 \\
\hline
\end{tabular}

Data presented as $n$ (\%) unless otherwise indicated. *Routine opt-out pregnancy screening was introduced in Alberta in 1998. IQR Interquartile range

A retrospective review of demographic and clinical characteristics, as a series of secondary analyses in this cohort over the study period, was performed.

\section{Outcomes of interest}

The objective of the present retrospective review was to describe the female population presenting for HIV care in southern Alberta from 1982 to 2006 and to examine demographic changes over time. The characteristics at first presentation with HIV that were focused on were: age, self-reported ethnicity, marital status, highest achieved education level, reason for HIV testing, hepatitis $\mathrm{C}$ virus coinfection, country of birth and initial CD4 cell count at presentation to the Southern Alberta HIV Clinic (SAC). Likely risk activity for HIV acquisition was assigned by a clinician according to a standard hierarchy. Data were stratified according to date of presentation (Pre-HAART [defined 
TABLE 2

Characteristics of male and female patients accessing HIV care in southern Alberta from 1982 to 2006

\begin{tabular}{|c|c|c|c|}
\hline & $\begin{array}{l}\text { Female } \\
(n=339)\end{array}$ & $\begin{array}{c}\text { Male } \\
(n=2055)\end{array}$ & $\mathbf{P}$ \\
\hline Age at presentation, years, mean \pm SD & $32.9 \pm 10.7$ & $35.5 \pm 9.42$ & $<0.001$ \\
\hline Median education level & High school & High school & \\
\hline Birth outside of Canada & $124(36.6)$ & $304(14.7)$ & $<0.001$ \\
\hline \multicolumn{4}{|l|}{ Ethnicity } \\
\hline Caucasian & $142(41.9)$ & $1582(77.0)$ & $<0.001$ \\
\hline Black & $98(28.9)$ & $100(4.9)$ & $<0.001$ \\
\hline Aboriginal/Métis & $73(21.5)$ & $179(8.7)$ & $<0.001$ \\
\hline Other & $16(0.9)$ & $91(4.4)$ & 0.87 \\
\hline Unknown & $10(2.9)$ & $103(5.0)$ & \\
\hline \multicolumn{4}{|l|}{ Marital status } \\
\hline Single & $68(20.1)$ & $414(20.1)$ & 0.99 \\
\hline Common law/married & $123(36.3)$ & $550(26.8)$ & $<0.001$ \\
\hline Divorced/separated/widower & $69(20.4)$ & $241(11.7)$ & $<0.001$ \\
\hline Never married & $44(13.0)$ & $646(31.4)$ & $<0.001$ \\
\hline Unknown & $35(10.3)$ & $204(9.9)$ & \\
\hline \multicolumn{4}{|l|}{ Risk factor for HIV } \\
\hline Heterosexual & $148(43.7)$ & $177(8.6)$ & $<0.001$ \\
\hline Heterosexual and endemic area & $65(19.2)$ & $50(2.4)$ & $<0.001$ \\
\hline Intravenous drug use & $106(31.3)$ & $282(13.7)$ & $<0.001$ \\
\hline Homosexual/bisexual & $1(0.3)$ & $1325(64.5)$ & $<0.001$ \\
\hline $\begin{array}{l}\text { Homosexual/bisexual intravenous } \\
\text { drug use }\end{array}$ & $0(0.0)$ & $165(8.0)$ & $<0.001$ \\
\hline Hemophilia/blood transfusion & $16(4.7)$ & $45(2.2)$ & 0.0076 \\
\hline Maternal fetal & $2(0.6)$ & $4(0.2)$ & 0.20 \\
\hline Unknown & $1(0.3)$ & $7(0.3)$ & \\
\hline \multicolumn{4}{|l|}{ Reason for testing } \\
\hline Patient request & $71(20.9)$ & $777(37.8)$ & $<0.001$ \\
\hline Physician request & $65(19.2)$ & $355(17.3)$ & 0.39 \\
\hline Contact & $50(14.7)$ & $187(9.1)$ & 0.001 \\
\hline Illness & $61(18.0)$ & $539(26.2)$ & 0.001 \\
\hline Routine pregnancy screening & $29(8.6)$ & $0(0.0)$ & - \\
\hline Immigration & 31 (9.1) & 37 (1.8) & $<0.001$ \\
\hline Insurance & $9(2.7)$ & $44(2.1)$ & 0.55 \\
\hline Blood & $9(2.7)$ & $63(3.1)$ & 0.69 \\
\hline Other screening & $7(2.1)$ & $14(0.7)$ & 0.016 \\
\hline Unknown & $7(2.1)$ & 39 (1.9) & 0.83 \\
\hline $\begin{array}{l}\text { CD4 count at presentation, } \\
\text { median (IQR) }\end{array}$ & $367(378)$ & 341 (398) & 0.001 \\
\hline HCV coinfection & $90(26.5 \%)$ & $299(14.5 \%)$ & $<0.001$ \\
\hline
\end{tabular}

Data presented as $n$ (\%) unless otherwise indicated. *Routine opt-out pregnancy screening was introduced in Alberta in 1998. IQR Interquartile range

as before 1997] compared with HAART [defined as 1997 and after]). Additionally, female and male populations were compared using the same parameters.

Testing behaviours among women with different risk factors for HIV, including the impact of opt-out pregnancy screening, were reviewed. The median CD4 counts at presentation of women with different reasons for HIV testing were also examined.

\section{Statistical analyses}

Tests for association were performed using a $\chi^{2}$ test, or a Fisher's exact test as appropriate. Differences between sexes in continuous variables, such as baseline median CD4 counts and age at presentation, were evaluated using a Mann-Whitney and two-sample $t$ test, respectively. In all analyses, patients with missing data were excluded from that particular analysis but were included for all others where data were present. All analyses were two-tailed, with statistical significance evaluated at the 0.05 level.
TABLE 3

Reasons for HIV testing among women with different risk factors for HIV

\begin{tabular}{|c|c|c|c|}
\hline Reason for HIV test & $\begin{array}{c}\text { Heterosexual } \\
\text { women }(n=148)\end{array}$ & $\begin{array}{l}\text { Heterosexual } \\
\text { women from } \\
\text { endemic areas } \\
\quad(n=65)\end{array}$ & $\begin{array}{c}\text { Female } \\
\text { injection drug } \\
\text { users }(n=106)\end{array}$ \\
\hline Patient request & $27(17.0)$ & $2(3.7)$ & $41(38.7)$ \\
\hline Physician request & $24(15.1)$ & $10(18.5)$ & $27(25.5)$ \\
\hline Contact & 37 (23.3) & $3(5.6)$ & $9(8.5)$ \\
\hline Illness & $26(16.4)$ & $7(13.0)$ & $23(21.7)$ \\
\hline Pregnancy screening & $9(6.1)$ & $18(27.7)$ & $2(1.9)$ \\
\hline Immigration & $11(6.9)$ & $20(37.0)$ & $0(0.0)$ \\
\hline Insurance & $7(4.4)$ & $0(0.0)$ & $0(0.0)$ \\
\hline Blood & $1(0.1)$ & $0(0.0)$ & $0(0.0)$ \\
\hline Other screening & $4(2.5)$ & $0(0.0)$ & $1(0.9)$ \\
\hline Unknown & $2(1.3)$ & $2(2.8)$ & $3(2.8)$ \\
\hline
\end{tabular}

\section{RESULTS}

Demographic characteristics of women presenting to SAC

From 1982 to 2006, 339 women and 2055 men with HIV presented to the SAC. The absolute number and proportion of women presenting with HIV have increased substantially during this time. From 1982 to 1996 , women accounted for $7.5 \%$ of new patients, whereas from 1997 to 2006, the proportion of new patients who were female increased to $21.5 \%$. The peak year for new diagnoses for women was 2006 (38 cases) while men experienced their peak 16 years earlier in 1990 (141 cases) (Figure 1).

The demographic characteristics of women presenting to SAC from 1982 to 2006 are described in Table 1. Over time, the female population presenting for HIV care in southern Alberta has become more diverse. Before 1997, most women diagnosed with HIV were Caucasian, and the main risk factor for HIV was heterosexual activity. From 1997 onward, women presenting for HIV care were significantly more likely to be black (35.2\% versus $12.6 \%, \mathrm{P}<0.001$ ) or Aboriginal/Métis ( $24.5 \%$ versus $13.7 \%, \mathrm{P}=0.03$ ). Heterosexual intercourse (excluding women from endemic areas) remained the most common risk factor for women but accounted for a significantly smaller proportion of women presenting post-HAART than previously $(37.7 \%$ versus $58.9 \%, \mathrm{P}<0.001)$.

Compared with men, women tended to present at a younger age ( 32.9 versus 35.5 years of age, $\mathrm{P}<0.001$ ) (Table 2 ) and were more likely to have been in a committed relationship at some point $(56.7 \%$ versus $38.5 \%, \mathrm{P}<0.001)$. Women were more likely to be Aboriginal/Métis ( $21.5 \%$ versus $8.7 \%, \mathrm{P}<0.001)$, black $(28.9 \%$ versus $4.9 \%, \mathrm{P}<0.001)$, or born outside of Canada (36.6\% versus $14.7 \%, \mathrm{P}<0.001)$.

\section{Reasons for HIV testing}

Women in this population had a wide variety of reasons for HIV testing (Table 1). Reasons for testing changed as opt-out pregnancy screening was introduced in 1998 and mandatory HIV screening, as part of the immigration process, was implemented in $2002(1,13)$. Among women with different risk factors, there was considerable heterogeneity of reasons for undergoing testing (Table 3). Female IDUs were more likely to discover their HIV-positive status due to patient requested testing $(38.7 \%$ versus $12.9 \%, \mathrm{P}<0.001)$ or physician requested testing $(25.5 \%$ versus $16.3 \%, \mathrm{P}=0.049)$. In contrast, heterosexual women from endemic areas were less likely than other women to discover their status as a result of patient-requested testing $(3.1 \%$ versus $25.4 \%, \mathrm{P}=0.004)$. Compared with men, women were significantly less likely to be diagnosed as a result of patient-initiated testing $(20.9 \%$ versus $37.8 \%, \mathrm{P}<0.001)$ or illness $(18.0 \%$ versus $26.2 \%$, $\mathrm{P}<0.001$ ) (Table 2). Even when pregnancy screening was excluded, women were more likely to be diagnosed through population-based screening $(18.1 \%$ versus $7.7 \%, \mathrm{P}<0.001)$.

CD4 counts were generally associated with the reason for HIV testing (Figure 2). Women diagnosed via patient request had significantly 


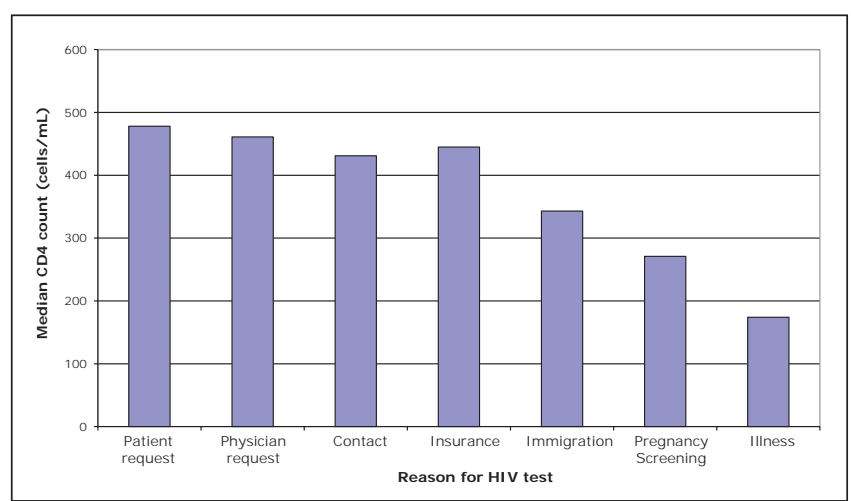

Figure 2) Median CD4 counts at presentation among HIV-positive women stratified according to reason for testing

higher median CD4 counts than women diagnosed as a result of pregnancy screening ( 478 cells $/ \mathrm{mL}$, interquartile range $[\mathrm{IQR}]=370$ cells $/ \mathrm{mL}$ versus 271 cells $/ \mathrm{mL}, \mathrm{IQR}=256$ cells $/ \mathrm{mL}, \mathrm{P}=0.001)$ or illness $(478$ cells $/ \mathrm{mL}$, $\mathrm{IQR}=370$ cells $/ \mathrm{mL}$ versus 174 cells $/ \mathrm{mL}, \mathrm{IQR}=328$ cells $/ \mathrm{mL}, \mathrm{P}<0.001$ ).

\section{Impact of opt-out pregnancy screening}

Opt-out pregnancy screening accounted for $12.7 \%$ of HIV-positive tests in women after its introduction in 1998. Women diagnosed as a result of pregnancy screening tended to be younger than women diagnosed for other reasons (26.6 versus 32.9 years of age, $\mathrm{P}<0.001$ ) and were more likely to be black $(62.1 \%$ versus $25.8 \%, \mathrm{P}<0.001)$ (Table 4$)$.

\section{DISCUSSION}

In the population reviewed, the absolute number and proportion of women being diagnosed with HIV have increased substantially over the past decade. Before 1997, the majority of HIV-positive women were heterosexual Caucasians. Since then, our female HIV-positive population has become more diverse, with newly diagnosed women more likely to be from vulnerable groups. In keeping with previous studies (8), black and Aboriginal women are overrepresented. Additionally, more than one-third of our female patients were born outside of Canada, with more than one-half of these women immigrating from HIV-endemic countries.

Women diagnosed with HIV after requesting testing had a median CD4 count of 478 cells $/ \mathrm{mL}$, which was higher than most women diagnosed by other means. However, only one in five women in our population discovered their HIV-positive status as a result of a patientinitiated test, a proportion which did not change over the study period. Previous studies suggest that self-perception of HIV risk is one determinant of HIV testing $(11,14,15)$ and in keeping with this, female IDUs were more likely than other women to learn their HIV status as a result of patient-initiated testing. Since HIV infection in our population was most commonly diagnosed in women with no risk factors for HIV, aside from heterosexual exposure, the low rate of patient-initiated testing may suggest that many women may be in denial or may perceive themselves erroneously to be low-risk for HIV. Other studies have suggested that even individuals who are aware of their risk factors for HIV often delay testing (12). Social stigmatization, language barriers, financial limitations and cultural beliefs may also contribute to low rates of patient-initiated testing. The factors influencing HIV testing among women from HIV-endemic countries merit further consideration, given that $<4 \%$ of these women initiated HIV testing.

In the United States, the Centers for Disease Control and Prevention recommends routine, voluntary HIV screening for patients in all health care settings between 13 and 64 years of age and repeat screening at least annually for those at high risk (16). Previous guidelines had focused on testing high-risk individuals and patients in areas where the prevalence of HIV was $>1 \%$. The new recommendations were intended to increase HIV screening, diagnose HIV earlier, identify patients who are unaware of their HIVpositive status so that they can receive treatment and reduce HIV
TABLE 4 Sociodemographic and clinical characteristics of women
presenting with HIV diagnosed as a result of opt-out
pregnancy screening in southern Alberta

\begin{tabular}{lc}
\hline & $\mathbf{( n = 2 9 )}$ \\
\hline Age at presentation, years mean \pm SD & $26.6 \pm 5.9$ \\
Ethnicity & \\
Black & $18(62.1)$ \\
Aboriginal & $6(20.7)$ \\
Caucasian & $4(13.8)$ \\
Unknown & $1(3.4)$ \\
Birth outside of Canada & $18(62.1)$ \\
Risk factor & \\
Heterosexual & $9(31.0)$ \\
Heterosexual and endemic area & $18(62.1)$ \\
Heterosexual and intravenous drug use & $2(6.9)$ \\
Marital status & \\
Married/common law & $14(48.3)$ \\
Single & $10(34.5)$ \\
Divorced & $1(3.4)$ \\
Never married & $1(3.4)$ \\
Not available & $3(10.3)$ \\
CD4 count at diagnosis, median (IQR) & $271(256)$ \\
Hepatitis C virus coinfection & $3(10.3)$ \\
\hline Data presented as $n(\%)$ uns
\end{tabular}

Data presented as $n$ (\%) unless otherwise indicated. IQR Interquartile range

transmission. By contrast, current Canadian guidelines recommend voluntary counselling and risk-based testing for HIV (17), but this may lead to delayed diagnosis for many women in our population. Although women diagnosed via physician-initiated testing tended to have CD4 counts that were comparable with women who initiated HIV testing, only one in five women were diagnosed as a result of a physician-requested test. Nearly the same number of women were diagnosed by healthy population-based screening, most notably optout pregnancy screening.

Data from pregnancy screening are often used for sentinel serosurveillance $(8,18)$ but likely underestimate the prevalence of HIV infection in the heterosexual population. Although $>95 \%$ of pregnant women in Alberta are screened, women who opt out are actually three times more likely to be HIV positive (19) and often do so based on an erroneous assessment of their risk for HIV (20). Obviously, women who never become pregnant are also missed by this screening method. Pregnancy screening in our population mainly diagnosed a specific subset of young, black women from HIV-endemic countries. We were not able to determine whether these patients came to Canada before the implementation of mandatory HIV testing during the immigration process in January $2002(1,13)$, were diagnosed initially at immigration and lost to follow-up, or were infected after arrival. The low median CD4 count of women in our population diagnosed via pregnancy screening is concerning, because it may suggest a delay in diagnosis. A recent study suggests that initiating HAART when CD4 counts are between 351 cells $/ \mathrm{mL}$ to 500 cells $/ \mathrm{mL}$ improves survival rates by $70 \%$ (3); the median CD4 count in our female cohort after the introduction of HAART was only 347 cells $/ \mathrm{mL}$, which indicates that one-half of our women were unable to benefit from early treatment. Aside from the health implications, previous studies in our population have shown that the direct costs associated with HIV infection are inversely related to CD4 count at presentation (4). Data from the United States suggests that expanded screening is cost-effective even when the prevalence of undiagnosed HIV infection is as low as $0.20 \%$ (21). Given these factors, there may be a rationale for expanded HIV screening in our population.

There are some limitations that should be considered in generalizing these findings to the rest of Canada. Our results are those of a 
retrospective, observational study. There was a small number of women compared with men in our population and we may not have had sufficient power to detect small differences. Additionally, our population may be unique in terms of the high proportion of immigrants from subsaharan Africa; even within Alberta, there are considerable demographic differences between northern and southern Alberta $(10,12,22)$. The length of our study period and the comprehensive nature of a geographically defined population may mitigate some of these limitations.

In southern Alberta, women from vulnerable groups appear to be at disproportionate risk for HIV infection. Women are less likely than men to be diagnosed due to patient request, and this may be related to lower CD4 counts at presentation. Further research is needed to determine strategies for prevention and diagnosis in women, especially women from HIV-endemic countries. In particular, the impact of expanded HIV screening merits further consideration.

DISCLOSURES: The authors do not have any conflicts of interest to declare.

FUNDING: Mr Raffa has received doctoral funding from the Canadian Institutes of Health Research (CIHR) and the Ontario Graduate Scholarship (OGS) Program

ACKNOWLEDGEMENTS: Thanks to Jonathan Snider and Michael Henry of SAC for their assistance with data extraction.

ETHICS APPROVAL: The work has been approved by the Conjoint Health Research Ethics Board, Ethics ID \# 17256.

\section{REFERENCES}

1. Public Health Agency of Canada. HIV and AIDS in Canada. Surveillance Report to December 31, 2009. Surveillance and Risk Assessment Division, Centre for Communicable Diseases and Infection Control, Public Health Agency of Canada, 2010. <www. phac-aspc.gc.ca/aids-sida/publication/survreport/2009/dec/pdf/2009Report-Rapport.pdf> (Accessed December 2010).

2. Marks G, Crepaz N, Senterfitt JW, Janssen RS. Meta-analysis of high-risk sexual behaviour in persons aware and unaware they are infected with HIV in the United States. J Acquir Immune Defic Syndr 2004:39:446-53.

3. Kitahata MM, Gange SJ, Moore RD and the North American AIDS Cohort Collaboration on Research and Design. Initiating rather than deferring HAART at a CD4+ count between 351-500 cells $/ \mathrm{mm}^{3}$ is associated with improved survival. [Abstract H-896b]. The 48th Annual ICAAC/IDSA 46th Annual Meeting. Washington, DC, October 25 to 28, 2008.

4. Krentz HB, Auld MD, Gill MJ. The high cost of medical care for patients who present late $(\mathrm{CD} 4<200$ cells $/ \mathrm{mL})$ with HIV infection. HIV Medicine 2004;5:93-8.

5. Hankins C. Gender, sex and HIV: How well are we addressing the imbalance? Curr Opin HIV AIDS 2008;3:514-20.

6. Public Health of Canada. HIV and AIDS in Canada. Surveillance Report to June 30, 2004. Surveillance and Risk Assessment
Division, Centre for Infectious Disease Prevention and Control, Public Health Agency of Canada, 2004. <www.phac-aspc.gc.ca/ publicat/aids-sida/haic-vsac0604/pdf/haic-vsac0604.pdf> (Accessed April 2010).

7. Simmonds K. HIV epidemiology in Alberta, 1999-2008. Alberta Health \& Wellness, Public Health Division, 2009. <www. aidscalgary.org/files/publications/AHW_EpiUpdate_2009.pdf> (Accessed December 2010).

8. Gatali M, Archibald C. Women and HIV. BMC Womens Health 2004;4(S1): S27-35.

9. Jayaraman GC, Preiksaitis JK, Larke B. Mandatory reporting of HIV infection and opt-out prenatal screening for HIV infection: Effect on testing rates. CMAJ 2003;168:679-82.

10. Hughes CA, Zuk D, Foisy M, Robinson J, Singh AE, Houston S. Prenatal screening and perinatal HIV transmission in Northern Alberta, 1999-2006. Am J Public Health 2009;99(S2):S412-16.

11. Houston S, Archibald CP, Strike C, Sutherland D. Factors associated with HIV testing among Canadians: Results of a population-based survey. Int J STD AIDS 1998;9:341-6.

12. Jayaraman GC, Bush KR, Lee B, Singh AE, Preiksaitis JK. Magnitude and determinants of first-time and repeat testing among individuals with newly diagnosed HIV infection between 2000 and 2001 in Alberta, Canada: Results from population-based laboratory surveillance. J Acquir Immune Defic Syndr 2004;37:1651-6.

13. Mill JE, Jackson RC, Worthington CA, et al. HIV testing and care in Canadian Aboriginal youth: A community based mixed methods study. BMC Infect Dis 2008;7:132.

14. Kellerman SE, Lehman JS, Lansky A, et al. HIV testing within at-risk populations in the United States and the reasons for seeking or avoiding HIV testing. J Acquir Immune Defic Syndr 2002;31:202-10.

15. Canadian Guidelines on Sexually Transmitted Infections. Ottawa, ON: Public Health Agency of Canada. [Revised January 2008]. <www.phac-aspc.gc.ca/std-mts/sti-its/pdf/sti-its-eng.pdf> (Accessed November 2009).

16. Archibald CP, Sutherland J, Geduld J, Sutherland D, Yan P. Combining data sources to monitor the HIV epidemic in Canada. J Acquir Immune Defic Syndr 2003;32(S1):S24-32.

17. Plitt SS, Singh AE, Lee BE, Preiksaitis JK. HIV seroprevalence among women opting out of prenatal HIV screening in Alberta, Canada: 2002-2004. Clin Infec Dis 2007;45:1640-3.

18. Campbell T, Bernhardt S. Factors that contribute to women declining antenatal HIV testing. Health Care Women Int 2003;24:544-51.

19. Zencovich M, Kennedy K, MacPherson DW, Gushulak BD. Immigration medical screening and HIV infection in Canada. Int J STD AIDS 2006;17:813-6.

20. Branson BM, Handsfield HH, Lampe MA, et al, for the Centers for Disease Control and Prevention. Revised recommendations for HIV testing of adults, adolescents, and pregnant women in health-care settings. MMWR Recomm Rep 2006;55(RR-14):1-17.

21. Paltiel AD, Walensky RP, Shackman BR, et al. Expanded HIV screening in the United States: Effect on clinical outcomes, HIV transmission, and costs. Ann Intern Med 2006; 145:797-806.

22. Bowker SL, Soskolne CL, Houston SC, et al. Human Immunodeficiency Virus (HIV) and hepatitis $\mathrm{C}$ virus (HCV) in a northern Alberta population. Can J Public Health 2004;95:188-92. 


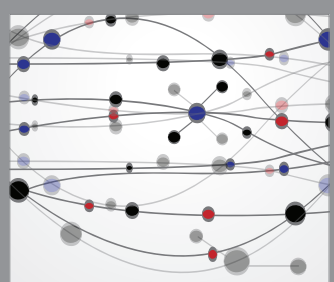

The Scientific World Journal
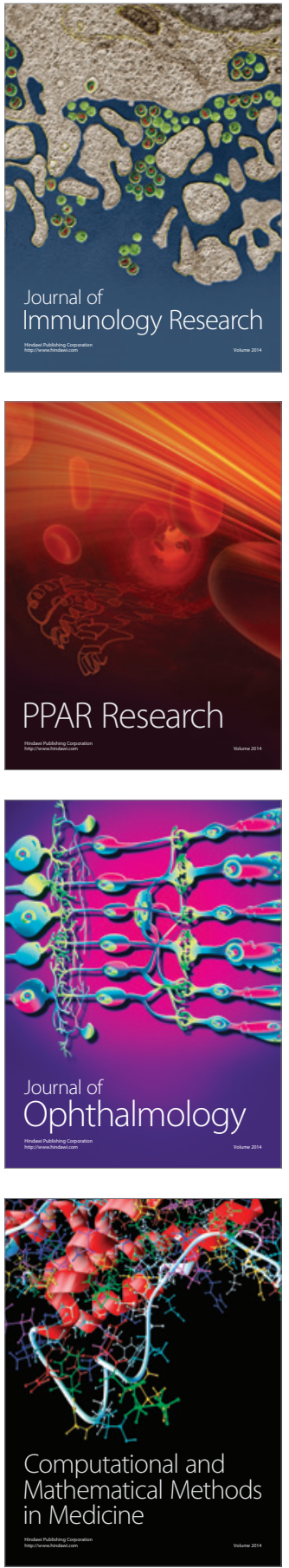

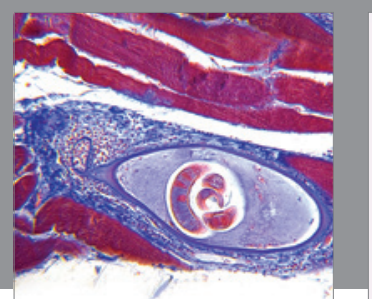

Gastroenterology Research and Practice

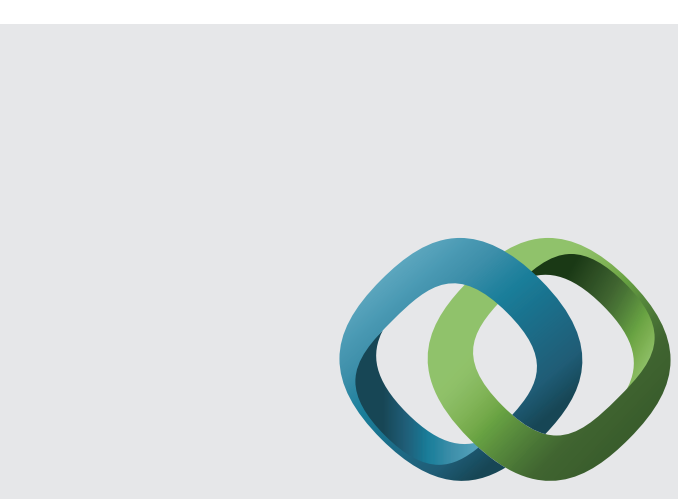

\section{Hindawi}

Submit your manuscripts at

http://www.hindawi.com
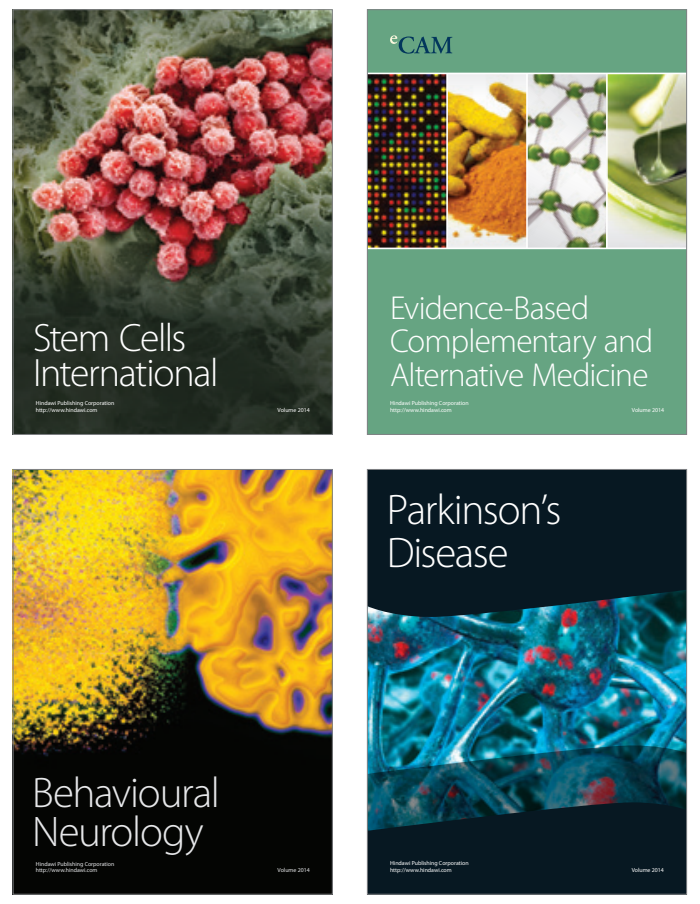
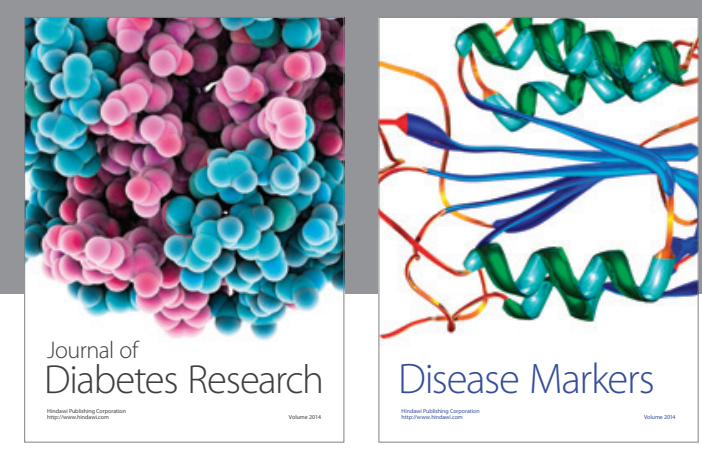

Disease Markers
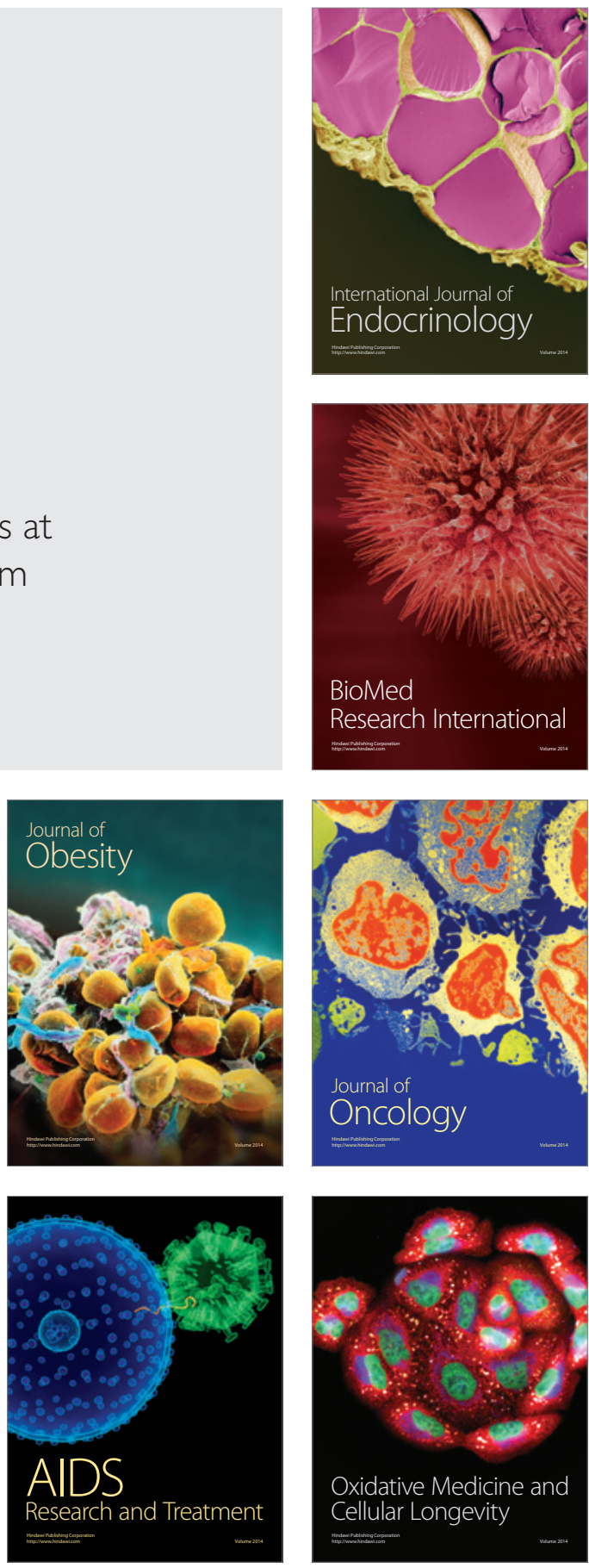